\title{
Recent advances in molecular pathology of
}

\section{craniopharyngioma [version 1; peer review: 2 approved]}

\author{
Sarah Larkin¹, Niki Karavitaki2,3 \\ ${ }^{1}$ Nuffield Department of Clinical Neurosciences, University of Oxford, Department of Neuropathology, John Radcliffe Hospital, \\ Oxford, OX3 9DU, UK \\ ${ }^{2}$ Centre for Endocrinology, Diabetes, and Metabolism, Birmingham Health Partners, Birmingham, B15 2TH, UK \\ 3Institute of Metabolism and Systems Research, College of Medical and Dental Sciences, University of Birmingham, Birmingham, \\ B15 2TT, UK
}

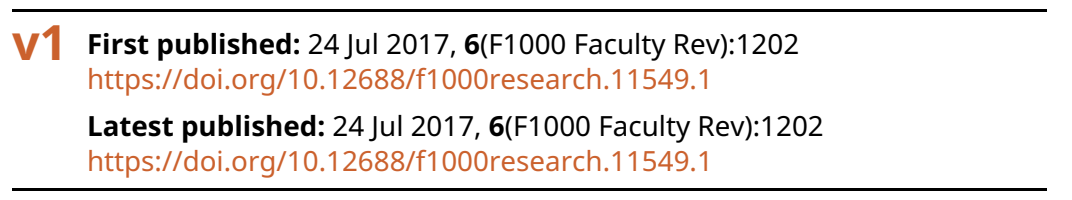

\section{Abstract}

Craniopharyngiomas are rare epithelial tumours arising along the path of the craniopharyngeal duct. Two major histological subtypes have been recognised, the papillary and the adamantinomatous. Craniopharyngiomas remain challenging tumours to manage and are associated with significant morbidities and mortality. Recent advances in the molecular pathology of these neoplasms have identified BRAF mutations in the papillary variant, offering promising options for targeted pharmacological treatment. The involvement of $\beta$-catenin and the Wnt pathway in the tumorigenesis of the adamantinomatous subtype has been previously established with the identification of stabilising mutations in exon 3 of CTNNB1. Further understanding of the pathogenesis of this subtype has been facilitated with the use of mouse models and xenograft experiments. It has been proposed that the clusters of cells with upregulated Wnt/ $\beta$-catenin signalling induce tumour formation in a paracrine manner; the complex interactions occurring between different cell populations need to be further clarified for further expansion of this hypothesis. This review outlines recent key advances in our understanding of the molecular pathology of craniopharyngiomas and discusses some of the challenges that need to be overcome for the development of targeted therapies that will hopefully improve the management and the outcomes of these patients.

\section{Keywords}

Craniopharyngioma, pharmacological treatment , pituitary , molecular pathology , BRAF mutations

\section{Open Peer Review \\ Approval Status \\ 1 2 \\ version 1 \\ 24 Jul 2017 \\ Faculty Reviews are review articles written by the prestigious Members of Faculty Opinions. The articles are commissioned and peer reviewed before publication to ensure that the final, published version is comprehensive and accessible. The reviewers who approved the final version are listed with their names and affiliations. \\ 1. Hermann Müller, Medical Campus University Oldenburg, Oldenburg, Germany \\ 2. Juan Pedro Martinez-Barbera, University \\ College London, London, UK}

Any comments on the article can be found at the end of the article. 
Corresponding author: Niki Karavitaki (n.karavitaki@bham.ac.uk)

Competing interests: The authors declare that they have no competing interests.

Grant information: The author(s) declared that no grants were involved in supporting this work.

Copyright: ( 2017 Larkin S and Karavitaki N. This is an open access article distributed under the terms of the Creative Commons Attribution License, which permits unrestricted use, distribution, and reproduction in any medium, provided the original work is properly cited.

How to cite this article: Larkin S and Karavitaki N. Recent advances in molecular pathology of craniopharyngioma [version 1; peer review: 2 approved] F1000Research 2017, 6(F1000 Faculty Rev):1202 https://doi.org/10.12688/f1000research.11549.1

First published: 24 Jul 2017, 6(F1000 Faculty Rev):1202 https://doi.org/10.12688/f1000research.11549.1 


\section{Introduction}

Craniopharyngiomas (CPs) are epithelial tumours (WHO grade I) arising along the path of the craniopharyngeal duct (embryonal structure connecting stomodeal ectoderm and the evaginated Rathke's pouch). Recent epidemiological data suggest incidence rates of $0.17-0.2$ cases per 100,000 people ${ }^{1-4}$. They show a bimodal age distribution with peak incidence rates in children aged 5-14 and adults aged 50-745. No gender differences have been reported $^{3,4}$.

Histologically, two primary subtypes have been recognised, the adamantinomatous (aCP) and the papillary (pCP). The aCP is the most common and macroscopically shows cystic and/or solid components, necrotic debris, fibrous tissue, and calcification (especially common in children). The margins of aCP are sharp and irregular, often making the identification of the surgical planes difficult. The cytoarchitecture of aCP comprises a palisaded basal layer of small cells; above this, there is an intermediate layer of variable thickness composed of loose aggregates of stellate cells (termed "stellate reticulum") and a top layer facing into the cyst lumen with abruptly enlarged, flattened, and keratinised flat plate-like squamous cells. The flat squames are desquamated singly or in distinctive stacked clusters, forming nodules of wet keratin, often heavily calcified and apparent grossly as white flecks ${ }^{5,6}$. The pCP has almost exclusively been described in adults (14-50\% of adult cases and only up to $2 \%$ in children). Macroscopically, it tends to be solid or mixed with cystic and solid components, calcification is rare, and the cyst content is usually viscous and yellow. It is generally well circumscribed, and infiltration of adjacent brain tissue by neoplastic epithelium is less frequent than in aCP or even absent. Microscopically, it is composed of mature squamous epithelium forming pseudopapillae and of an anastomosing fibrovascular stroma without the presence of peripheral palisading of cells or stellate reticulum ${ }^{5,6}$.

The optimal management of CPs remains challenging, and the main options include surgery combined or not with radiotherapy; nonetheless, they can show aggressive and unpredictable behaviour with recurrence(s) difficult to treat ${ }^{7}$. Furthermore, these tumours are associated with significant long-term morbidity (mainly involving endocrine, visual, hypothalamic, neurobehavioural, and cognitive sequelae) and mortality, attributed to the damage of critical structures by the primary or recurrent tumour and/or to the adverse effects of therapeutic interventions ${ }^{8-11}$.

Better understanding of the molecular pathology of CPs is of major importance for the development of targeted therapies aiming to improve the outcomes of these patients. In recent years, there have been significant advances in this field, and we summarise them in this brief review.

\section{Mutations in BRAF are characteristic for $\mathrm{pCP}$, while aCP is associated with CTNNB1 mutations}

The involvement of $\beta$-catenin and the Wnt pathway in the tumorigenesis of aCP has been established, since stabilising mutations in exon 3 of $C T N N B 1$ that prevent phosphorylation and degradation of $\beta$-catenin have been identified in $\mathrm{aCPs}^{12}$. However, until recently, the genetic event underlying the development of $\mathrm{pCP}$ had remained unclear. Several studies employing whole exome sequencing, next-generation panel sequencing, pyrosequencing, and Sanger sequencing have demonstrated the presence of activating mutations in BRAF (V600E) in pCPs. Their reported prevalence varies according to the sequencing method used and ranges from 81 to $100 \%{ }^{13-16}$. Extensive analysis of aCPs using the same methods has not identified recurrent mutations other than those in exon 3 of $C T N N B 1^{13-15}$. The lack of genetic complexity seen in these tumours is typical of their benign behaviour, and the almost-perfect segregation of mutation with tumour variant ${ }^{16}$ coupled with the existence of a BRAF V600E mutation-specific antibody (VE1) provides a useful diagnostic tool for specimens with scant epithelium or where diagnosis is challenging; it should be noted that there is some concern about the specificity of this antibody in pituitary tissue, necessitating cautious interpretation $^{17-19}$. Much more promising, however, is the possibility for targeted pharmacological treatment with agents directed against the $B R A F$ (V600E) mutation.

\section{BRAF (V600E) mutations offer the possibility for targeted pharmacological treatment}

The finding that most pCPs harbour a BRAF (V600E) mutation has opened up the exciting possibility of repurposing existing drugs for the treatment of pCP cases refractory to surgery and radiotherapy. Pharmacological agents that specifically target and inhibit mutant BRAF (V600E) are very effective in malignant tumours positive for this mutation. Although the development of resistance to these agents is a potential drawback, the addition of other inhibitors of the MAPK pathway (e.g. trametinib, which inhibits MEK) can increase their efficacy ${ }^{20}$ and reduce the risk of cutaneous squamous-cell carcinoma, a common complication of BRAF inhibitor treatment.

Two recent reports have shown significant reduction in tumour volume in cases of treatment-refractory pCP. Aylwin and colleagues $^{21}$ described a patient with progressive visual deterioration due to a recurrent $\mathrm{pCP}$ previously managed with three surgeries and fractionated radiotherapy. The tumour harboured $B R A F$ (V600E) mutation and the patient was treated with vemurafenib. Stabilisation of vision was achieved within two weeks, along with a dramatic reduction in tumour size. Near-complete radiological remission occurred after three months, but the patient developed cerebrospinal fluid leak, pneumocephalus, and meningitis, necessitating antimicrobial therapy and surgical repair. Treatment was interrupted after three months, but the $\mathrm{CP}$ recurred within six weeks and vemurafenib was restarted. Tumour growth was stabilised until seven months after treatment initiation when progressive regrowth was detected. The second report from Brastianos and colleagues ${ }^{22}$ described a patient with multiply recurrent pCP with BRAF (V600E mutation). Four surgical decompressions were unsuccessful at controlling the growth of the tumour, which had a large cystic component. The patient suffered bilateral optic neuropathy and panhypopituitarism. Treatment was initially dabrafenib monotherapy, and after 17 days the solid and cystic components decreased by $50 \%$ and $70 \%$, respectively. At day 21, the MEK inhibitor trametinib was added for a further 14 days to reduce the likelihood of resistance to BRAF inhibition. This regime led to solid and cystic components of the tumour 
decreasing in total by $85 \%$ and $81 \%$, respectively. Subsequently, the patient underwent endoscopic transsphenoidal resection followed by radiotherapy and has remained symptom free 18 months after radiation.

Both cases illustrate the promising potential for the use of BRAF (V600E) inhibitors and remain to be validated with clinical trials.

\section{aCP and pCP have different epigenomic and transcriptional signatures}

As well as their genetic differences, $\mathrm{CP}$ variants have been shown to have different epigenomic and transcriptomic signatures. Analysis of the most variably methylated $\mathrm{CpG}$ sites by both unsupervised hierarchical clustering and principal component analysis identified two distinct methylation clusters that separated $\mathrm{aCP}$ and $\mathrm{pCP}^{15}$. Additionally, unsupervised consensus clustering using the most variably expressed genes identified by microarray analysis resulted in clear separation of the two subtypes, indicating that they likely have distinct gene expression signatures ${ }^{15,23}$. Analysis of mRNA expression demonstrated up-regulation of $\mathrm{Wnt} / \beta$-catenin pathway targets in aCP (LEF1 and AXIN2) and also components of the hedgehog signalling pathway (GLI2, PTCHI, and $S H H)$. Additionally, the stem cell marker PROM1 (encoding CD133) was overexpressed. These findings are in keeping with previous published data from the same group that suggest the activation of Wnt and sonic hedgehog $(\mathrm{SHH})$ pathways in the cell clusters of aCP (see below) ${ }^{24-28}$. For a detailed discussion of the opportunities for therapy targeting these upregulated pathways, see 29.

Interestingly, neither the methylation nor the mRNA expression signatures of paediatric aCP and adult aCP separated when analysed as described above, suggesting that they may not be distinct at the epigenomic or transcriptional level ${ }^{15}$.

\section{Cluster cells have a functional role in the promotion of invasion}

The cells that accumulate $\beta$-catenin in aCP are small in number and often, but not always, accumulate to form small clusters with a whorl-like pattern near the infiltrating edges of the tumour ${ }^{26,30-35}$. The function of these cluster cells remains enigmatic, but they represent a population strikingly different from the bulk of the tumour.

A mouse model of aCP demonstrated that CTNNB1 mutation in Rathke's pouch progenitor cells is sufficient to drive aCP tumorigenesis. Expression of CTNNB1 lacking exon 3 (degradationresistant $\beta$-catenin) under the control of Hesx 1 in the early stages of mouse pituitary development results in the formation of tumours that closely resemble human $\mathrm{aCP}$, although they lack some of the regressive changes seen in the human tumour, e.g. wet keratin. Mutation of $\beta$-catenin in undifferentiated Rathke's pouch progenitors is sufficient to drive tumorigenesis of aCP, but once lineage commitment has occurred, the mutation is no longer tumorigenic ${ }^{36}$. Interestingly, although $C T N N B 1$ mutation was present in the whole population of progenitor cells, there was only cytosolic and/or nuclear accumulation of $\beta$-catenin in the characteristic cell clusters near the invading tumour edge ${ }^{36}$, indicating that an event other than CTNNB1 mutation determined which cells formed clusters.
Hölsken et al. harvested cluster cells from human aCP using laser capture microdissection and sought to determine whether they harboured an activating mutation in exon 3 of the $\beta$-catenin gene and whether the Wnt pathway was activated by quantifying Axin 2 and $B M P 4$. The cluster cells expressed mutated CTNNB1, along with the surrounding tumour cells, but only the cluster cells expressed elevated levels of Axin2 and BMP4 RNA and protein. The authors concluded that $C T N N B 1$ mutation is not sufficient to drive nuclear $\beta$-catenin accumulation ${ }^{26}$. These cluster cells were also found to express Fascin, a Wnt target gene with a role in cytoskeletal organisation and cell migration ${ }^{24,26}$. Downregulation of both $\beta$-catenin and fascin expression in human primary aCP tumour cells using siRNA impaired their motility and migrational capacity $^{24}$. The study did not separate cells derived from different features of the aCP prior to culture, so the culture was likely to contain non-cluster cells as well as the cluster cells the authors sought to characterise. Mutation in CTNNB1 was present in $66 \%$ of aCPs, but its effect on the behaviour of the cells was not explored $^{24}$. However, the observation that siRNA-mediated downregulation of $\beta$-catenin or fascin impairs motility in primary human aCP cells suggests a potential role for $\beta$-catenin, fascin, and (by inference) the cluster cells in the invasion into surrounding brain. Additionally, the same group demonstrated that claudin, a tightjunction component, was expressed in the finger-like protrusions of aCP but was absent from the cell clusters; this pattern of expression is consistent with a migratory phenotype for the cluster cells. Furthermore, inhibition of claudin expression increased significantly the motility of aCP tumour cells, and claudin expression was significantly lower in invasive than in non-invasive $\mathrm{aCPs}^{27}$.

Further insight into the role of cluster cells in the pathogenesis of aCP was provided in a study by Stache et al., who used a xenotransplant model of human aCP in immunodeficient mice. Serial sectioning of a whole aCP xenograft provided a reconstruction of the formation of the finger-like protrusions that invade surrounding brain. From these serial sections, the authors inferred that the cluster cells themselves extrude through the palisading epithelial layer that encases the tumour to infiltrate the surrounding brain and then become enclosed again by a palisading epithelial layer to form the whorls characteristic of the finger-like protrusions of aCP. Consistent with this model for infiltration, the xenografts and human tumour specimens showed increased proliferation of the palisading cells and expression of $\mathrm{p} 21^{\mathrm{WAF} / \mathrm{Cip} 1}$ in the cluster cells, indicating cell cycle arrest. Although this model is a snapshot of the developing $\mathrm{aCP}$ and not a time course, the mechanism proposed is an attractive explanation for both the motile and the quiescent phenotype of cluster cells as well as their sustained presence in the infiltrating tumour projections.

\section{Pituitary stem cells have a paracrine role in the pathogenesis of aCP}

The cluster cells in aCP are a clearly distinct subpopulation, but their function within the tumour is not yet well understood. There is growing evidence for a population of anterior pituitary stem cells expressing Sox 2 that can give rise to the main anterior pituitary progenitor cell lineages and that, crucially, also have tumourinducing potential ${ }^{30,36}$. Andoniadou et al. created a mouse model 
that expresses degradation-resistant $\beta$-catenin in Sox $2^{+}$cells upon tamoxifen induction to determine whether these cells could give rise to tumours at the embryonic stage and also in adult mice. The embryonic-induced mice developed tumours similar to those seen in the Hesx 1 model $^{36}$, with identifiable $\beta$-catenin-accumulating cluster cells reminiscent of those in human aCP that were quiescent or slow-dividing (did not express Ki-67) and were undifferentiated (did not express lineage commitment markers $\alpha$ GSU and PIT1 $)^{37}$. In the adult-induced model, the pattern of $\beta$-catenin expression was more complex, with some cells showing nucleocytoplasmic accumulation.

Lineage tracing experiments used Sox $2^{+}$cells simultaneously expressing both degradation-resistant $\beta$-catenin and yellow fluorescent protein (YFP) aiming to identify both these tumour progenitor cells and their descendants ${ }^{37}$. Interestingly, after induction of degradation-resistant $\beta$-catenin, the majority of tumour cells formed did not express YFP. However, there were populations of YFP-expressing cells adjacent to the tumour cells, some of which formed clusters. These findings indicate that the tumour cells were not derived from Sox $2^{+}$cells expressing degradation-resistant $\beta$-catenin. However, nucleocytoplasmic accumulation of $\beta$-catenin was observed in tumour cells that did not express YFP (and so were not derived from the Sox $2^{+}$progenitor cells), suggesting that this accumulation and activation of the Wnt pathway is noncell-autonomous and may occur as a result of signalling from the adjacent $\mathrm{Sox}^{+}$cell population. Indeed, the $\beta$-cateninaccumulating, YFP- $^{-}$tumour cells were often found in close proximity to the $\mathrm{YFP}^{+}$cells, suggesting a functional relationship ${ }^{37}$.

Expression of degradation-resistant $\beta$-catenin in Sox $2^{+}$cells leads to the formation of $\beta$-catenin-accumulating cell clusters that resemble those in human aCP, implicating Sox $2^{+}$progenitor cells as the cells in which the tumour-initiating mutation in $\beta$-catenin occurs. However, these cells do not give rise in an autonomous manner to the tumour cells as would be expected if they were true mutation-sustaining cancer stem cells. Instead, they appear to drive tumour formation in a paracrine manner by inducing tumorigenic events in adjacent cells. The authors propose that induction of degradation-resistant $\beta$-catenin initiates a brief period of proliferation in a proportion of $\mathrm{Sox} 2^{+}$cells. The resulting daughter cells then form the $\beta$-catenin-accumulating clusters that are characteristic of aCP. These clusters become quiescent and secretory, signalling by means of secretory proteins including members of the fibroblast growth factor (FGF), transforming growth factor beta (TGF $\beta$ ), epithelial growth factor, and $\mathrm{SHH}$ pathways, along with pro-inflammatory cytokines and chemokines, ${ }^{30}$ to induce transformation in surrounding cells and perhaps modify the tumour microenvironment. It is these non-Sox $2^{+}$ derived cells that form the bulk of the tumour ${ }^{37}$.

The mouse paracrine model of aCP pathogenesis includes a stem-cell-like progenitor that sustains the oncogenic mutation but is not the cell-of-origin of the tumour (comprehensively reviewed in 38-40). There is considerable evidence to suggest that human aCP may follow the same pathogenic route. The cluster cells of human aCP are non-proliferative and express members of the FGF, TGF $\beta$, and SHH pathways ${ }^{25,26,30}$, and they are also nonproliferative and undifferentiated ${ }^{36,41}$. A representation of the different cell populations at the invading edge of aCP and some of the differentially expressed proteins and factors is shown in Figure 1. The tumour environment is a competitive one in which more proliferative cells will out-compete and replace their more indolent neighbours in a process termed somatic or clonal evolution (extensively reviewed in 42). This concept generally refers to aggressive tumours with a high degree of genetic inhomogeneity, in which particular mutations may confer survival advantages to subpopulations of cells, but it seems reasonable that, even in a tumour with a limited mutational landscape, a quiescent population of cells would quickly be replaced by proliferating cells unless they were performing a function essential for the pathogenesis of the tumour, as has been proposed by other authors ${ }^{38,40}$. Instead, even in highly invasive and destructive aCPs that destroy surrounding hypothalamic and pituitary tissue, clusters of $\beta$-catenin-accumulating, quiescent cells remain. Furthermore, these clusters are often located near to the invading tumour periphery, in regions where the proliferation of surrounding cells is high and selective pressure is likely to be significant. Reports differ as to the prevalence of CTNNB1 mutation in aCPs and sequencing of a bulk aCP tumour is likely to result in false negative results if the mutation is present only in cluster cells, which may constitute a small proportion of the bulk tumour and so fall below the limit of detection of the method employed. However, immunohistochemical studies have suggested that even in aCP with no obvious cell clusters, there are $\beta$-cateninaccumulating cells found distributed throughout the tumour ${ }^{35}$. This is useful from a diagnostic perspective but may also be indicative of the importance of these cells for tumour pathogenesis. Further experiments will be required to determine whether cluster cells are essential paracrine signalling hubs for tumour pathogenesis after the tumour-initiating mutation in $C T N N B 1$, but the current available evidence is consistent with this model.

\section{Mouse models, primary cell culture, and xenografts offer opportunities to study aCP pathogenesis}

Mouse models, primary cell cultures, and xenograft models are valuable tools for studying the pathogenesis of aCP, each of which has advantages for answering particular questions; however, none fully recapitulates the features of the human tumour. The mouse models (both Hesx1- and Sox2-driven ${ }^{36,37}$ ), while they allow the study and manipulation of tumorigenesis, lack some features of human aCP: for instance, they do not develop a defined palisading layer of epithelial cells at the invading edge of the tumour, nor do they show calcification or the anucleated ghost cells (wet keratin) that are pathognomonic for human aCP. It has been suggested that wet keratin is a feature of a more mature tumour and that the lack of this feature in the mouse models is likely a consequence of the relatively short period (weeks) over which the mouse tumour develops. A report by Scagliotti et $a l .{ }^{43}$ of an intrauterine-diagnosed congenital aCP at 23 weeks of gestation described the presence of wet keratin and calcium deposits in the tumour. This is comparable to the $2-5$-month period over which the Sox $2^{+}$aCP mouse model develops ${ }^{37}$, so perhaps the lack of wet keratin and calcification 


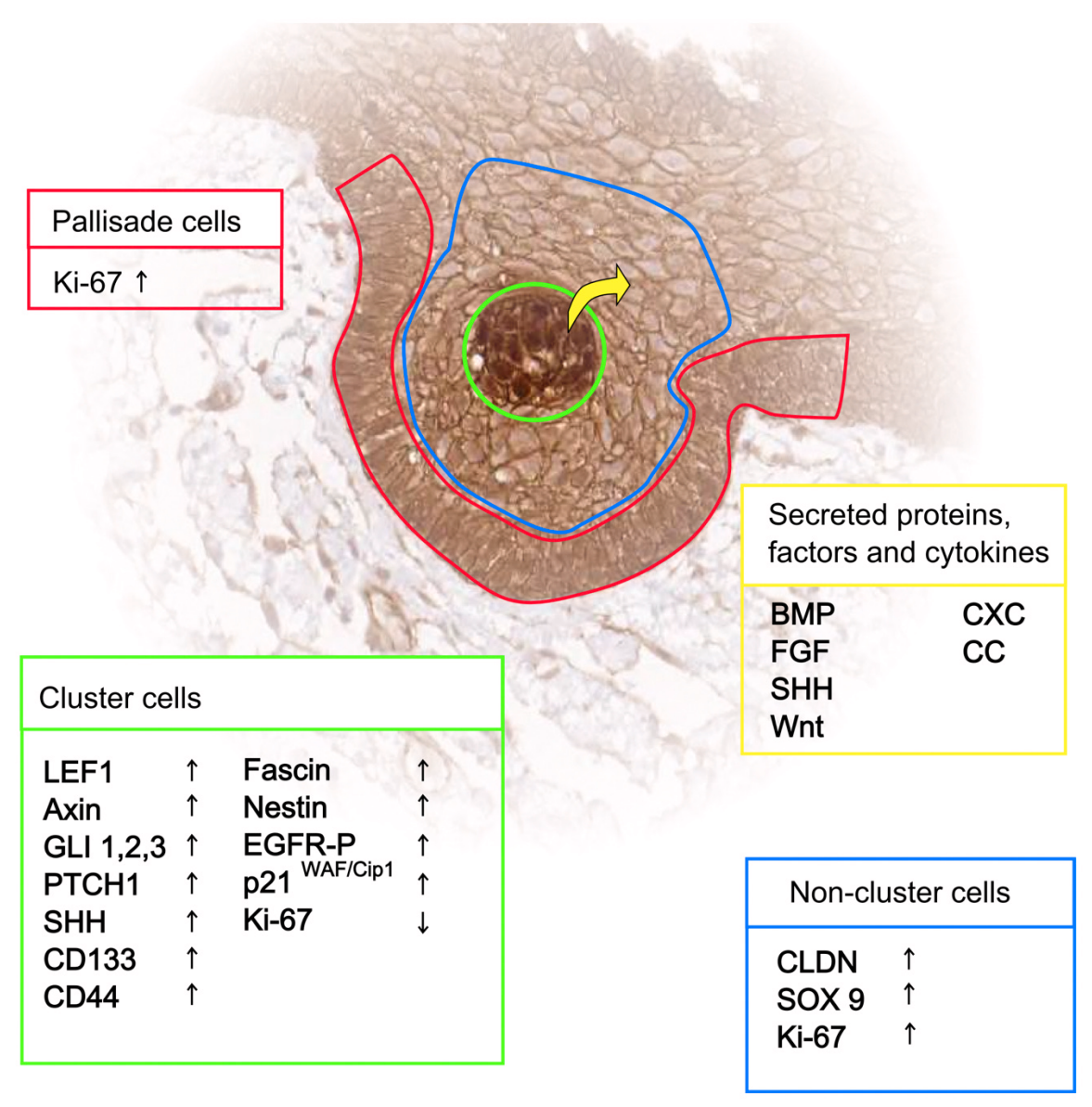

Figure 1. Subpopulations of cells at the invading edge of adamantinomatous craniopharyngioma. The relative expression of various targets and activity of signalling pathways vary according to cell type. BMP, bone morphogenetic protein; FGF, fibroblast growth factor; SHH, sonic hedgehog.

in the mouse tumour is due to species-specific differences in the pathogenesis of this tumour or perhaps the mouse model is lacking a facet of the human tumour that is not yet identified.

Primary human aCP cell cultures ${ }^{24}$ have the advantage of being derived from the human tumour and can be used to screen pharmacological agents relatively easily; however, the process of tissue disruption required for cell culture means that the complex architecture of the $\mathrm{aCP}$ is lost. Any functional relationship between the cluster cells and surrounding tumour is likely to be perturbed or destroyed. Furthermore, culture conditions cannot replicate microenvironmental signals to the tumour from surrounding tissue. It has not been tested whether aCP primary cells in culture develop cluster-like formations and the cultures have not been molecularly profiled. Greater characterisation of this model is needed to determine the extent of its utility in studies of human $\mathrm{aCP}$.

Xenograft models ${ }^{28}$ preserve the cytoarchitecture of the human aCP and provide a microenvironmental context (albeit from a different species) in which the aCP can grow and invade. However, opportunities for the manipulation of tumour pathogenesis are limited in this model, and its suitability for testing pharmacological agents may be compromised by the low availability of human tumour material and differences in responses to agents between species.

All the models discussed here have provided greater insight into the pathogenesis of aCP and represent useful tools for answering outstanding questions, but the particular advantages and disadvantages of each must be acknowledged and considered.

\section{Heterogeneity of aCP represents a challenge to the development of pharmacological treatment}

This review has highlighted the very different architecture and pathogenesis of $\mathrm{CP}$ variants. While the discovery of the $B R A F$ (V600E) mutation in pCP has afforded us an opportunity for a promising pharmacological intervention, recent progress in understanding aCP reveals a morphologically complex tumour with distinct cell populations that have differing functions and cells of origin. If the paracrine model for aCP tumorigenesis withstands further investigation, it presents a potential target for therapeutic intervention, namely the cluster cells that initiate and support tumorigenesis in surrounding cells. However, the stem-like properties of these cells make them difficult targets for cytotoxic agents, which are often ineffective against quiescent cells. Any targeted 
therapy aimed at disrupting the paracrine signalling between clusters and surrounding cells will require deeper understanding of the signalling events and the effect on the surrounding tumour.

\section{Conclusions}

Understanding of $\mathrm{CP}$ pathogenesis has increased considerably in recent years. The identification of $B R A F(\mathrm{~V} 600 \mathrm{E})$ mutations in $\mathrm{pCP}$ has led to the potential for new targeted pharmacological therapy. Our understanding of aCP has been greatly improved by mouse model and xenograft experiments revealing new and critical roles for $\beta$-catenin-accumulating cluster cells; however, there is still much to clarify about the complex interactions that occur between different cell populations within this neoplasm before we are in the position to develop effective targeted therapies.

\section{Competing interests}

The authors declare that they have no competing interests.

\section{Grant information}

The author(s) declared that no grants were involved in supporting this work.
1. Al-Dahmani K, Mohammad S, Imran F, et al:: Sellar Masses: An Epidemiological Study. Can J Neurol Sci. 2016; 43(2): 291-7. PubMed Abstract | Publisher Full Text

2. Nielsen EH, Feldt-Rasmussen U, Poulsgaard L, et al: Incidence of craniopharyngioma in Denmark $(n=189)$ and estimated world incidence of craniopharyngioma in children and adults. J Neurooncol. 2011; 104(3): 755-63. PubMed Abstract | Publisher Full Text

3. Olsson DS, Andersson E, Bryngelsson IL, et al:: Excess mortality and morbidity in patients with craniopharyngioma, especially in patients with childhood onset: a population-based study in Sweden. J Clin Endocrinol Metab. 2015; 100(2): 467-74.

PubMed Abstract | Publisher Full Text

4. Zacharia BE, Bruce SS, Goldstein $\mathrm{H}$, et al.: Incidence, treatment and survival of patients with craniopharyngioma in the surveillance, epidemiology and end results program. Neuro Oncol. 2012; 14(8): 1070-8. PubMed Abstract | Publisher Full Text | Free Full Text

5. Karavitaki N, Cudlip S, Adams CB, et al.: Craniopharyngiomas. Endocr Rev. 2006; 27(4): 371-97.

PubMed Abstract | Publisher Full Text

6. Larkin SJ, Ansorge O: Pathology and pathogenesis of craniopharyngiomas. Pituitary. 2013; 16(1): 9-17.

PubMed Abstract | Publisher Full Text

7. Karavitaki N: Management of craniopharyngiomas. J Endocrinol Invest. 2014; 37(3): 219-28.

PubMed Abstract | Publisher Full Text

8. Erfurth EM, Holmer $\mathrm{H}$, Fjalldal SB: Mortality and morbidity in adult craniopharyngioma. Pituitary. 2013; 16(1): 46-55. PubMed Abstract | Publisher Full Text

9. Gautier A, Godbout A, Grosheny C, et al:: Markers of recurrence and long-term morbidity in craniopharyngioma: a systematic analysis of 171 patients. $J$ Clin Endocrinol Metab. 2012; 97(4): 1258-67. PubMed Abstract | Publisher Full Text

10. Karavitaki N, Brufani C, Warner JT, et al.: Craniopharyngiomas in children and adults: systematic analysis of 121 cases with long-term follow-up. Clin Endocrinol (Oxf). 2005; 62(4): 397-409. PubMed Abstract | Publisher Full Tex

11. F Müller HL: Risk-adapted, long-term management in childhood-onse craniopharyngioma. Pituitary. 2017; 20(2): 267-81. PubMed Abstract | Publisher Full Text | F1000 Recommendation

12. Sekine $\mathrm{S}$, Shibata $\mathrm{T}$, Kokubu A, et al:: Craniopharyngiomas of adamantinomatous type harbor beta-catenin gene mutations. Am J Pathol. 2002; 161(6): 1997-2001. PubMed Abstract | Publisher Full Text | Free Full Text

13. F Brastianos PK, Taylor-Weiner A, Manley PE, et al.: Exome sequencing identifies BRAF mutations in papillary craniopharyngiomas. Nat Genet. 2014; 46(2): 161-5.

PubMed Abstract | Publisher Full Text | Free Full Text | F1000 Recommendation

14. Goschzik T, Gessi M, Dreschmann V, et al:: Genomic Alterations of Adamantinomatous and Papillary Craniopharyngioma. J Neuropathol Exp Neurol. 2017; 76(2): 126-34. PubMed Abstract | Publisher Full Text

15. Hölsken A, Sill M, Merkle J, et al.: Adamantinomatous and papillary craniopharyngiomas are characterized by distinct epigenomic as well as mutational and transcriptomic profiles. Acta Neuropathol Commun. 2016; 4: 20 PubMed Abstract | Publisher Full Text | Free Full Text

16. Larkin SJ, Preda V, Karavitaki N, et al.: BRAF V600E mutations are characteristic for papillary craniopharyngioma and may coexist with CTNNB1-mutated adamantinomatous craniopharyngioma. Acta Neuropathol. 2014; 127(6): 927-9. PubMed Abstract | Publisher Full Text | Free Full Text

17. Farzin M, Toon CW, Clarkson A, et al:: BRAF V600E mutation specific immunohistochemistry with clone VE1 is not reliable in pituitary adenomas. Pathology. 2014; 46(1): 79-80.

PubMed Abstract | Publisher Full Text

18. Mordes DA, Lynch K, Campbell S, et al.: VE1 antibody immunoreactivity in normal anterior pituitary and adrenal cortex without detectable BRAF V600E mutations. Am J Clin Pathol. 2014; 141(6): 811-5. PubMed Abstract | Publisher Full Text

19. Sperveslage J, Gierke M, Capper D, et al:: VE1 immunohistochemistry in pituitary adenomas is not associated with BRAF V600E mutation. Acta Neuropathol. 2013; 125(6): 911-2.

PubMed Abstract | Publisher Full Text

20. F Flaherty KT, Infante JR, Daud A, et al.: Combined BRAF and MEK inhibition in melanoma with BRAF V600 mutations. N Engl J Med. 2012; 367(18): 1694-703. PubMed Abstract | Publisher Full Text | Free Full Text | F1000 Recommendation

21. F Aylwin SJ, Bodi I, Beaney R: Pronounced response of papillary craniopharyngioma to treatment with vemurafenib, a BRAF inhibitor. Pituitary. 2016; 19(5): 544-6.

PubMed Abstract | Publisher Full Text | Free Full Text | F1000 Recommendation

22. F Brastianos PK, Shankar GM, Gill CM, et al.: Dramatic Response of BRAF V600E Mutant Papillary Craniopharyngioma to Targeted Therapy. J Natl Cancer Inst. 2016; 108(2): pii: djv310.

PubMed Abstract | Publisher Full Text | Free Full Text | F1000 Recommendation

23. Gump JM, Donson AM, Birks DK, et al:: Identification of targets for rational pharmacological therapy in childhood craniopharyngioma. Acta Neuropathol Commun. 2015; 3: 30.

PubMed Abstract | Publisher Full Text | Free Full Text

24. Hölsken A, Buchfelder M, Fahlbusch R, et al:: Tumour cell migration in adamantinomatous craniopharyngiomas is promoted by activated Wntsignalling. Acta Neuropathol. 2010; 119(5): 631-9. PubMed Abstract | Publisher Full Text

25. Hölsken A, Gebhardt M, Buchfelder M, et al:: EGFR signaling regulates tumor cell migration in craniopharyngiomas. Clin Cancer Res. 2011; 17(13): 4367-77. PubMed Abstract | Publisher Full Text

26. Hölsken A, Kreutzer J, Hofmann BM, et al.: Target gene activation of the Wnt signaling pathway in nuclear beta-catenin accumulating cells of adamantinomatous craniopharyngiomas. Brain Pathol. 2009; 19(3): 357-64. PubMed Abstract | Publisher Full Text

27. Stache $\mathrm{C}$, Hölsken $\mathrm{A}$, Fahlbusch $\mathrm{R}$, et al: Tight junction protein claudin-1 is differentially expressed in craniopharyngioma subtypes and indicates invasive tumor growth. Neuro Oncol. 2014; 16(2): 256-64. PubMed Abstract | Publisher Full Text | Free Full Text

28. F Stache C, Hölsken A, Schlaffer SM, et al:: Insights into the infiltrative behavior of adamantinomatous craniopharyngioma in a new xenotransplant mouse model. Brain Pathol. 2015; 25(1): 1-10. PubMed Abstract | Publisher Full Text | F1000 Recommendation 

craniopharyngioma: review and opportunities for practice. Neurosurg Focus. 2016; 41(6): E4. PubMed Abstract | Publisher Full Text

30. Andoniadou CL, Gaston-Massuet C, Reddy R, et al.: Identification of novel pathways involved in the pathogenesis of human adamantinomatous craniopharyngioma. Acta Neuropathol. 2012; 124(2): 259-71. PubMed Abstract | Publisher Full Text | Free Full Text

31. Buslei R, Nolde M, Hofmann B, et al:: Common mutations of beta-catenin in adamantinomatous craniopharyngiomas but not in other tumours originating from the sellar region. Acta Neuropathol. 2005; 109(6): 589-97. PubMed Abstract | Publisher Full Text

32. Hassanein AM, Glanz SM, Kessler HP, et al.: beta-Catenin is expressed aberrantly in tumors expressing shadow cells. Pilomatricoma, craniopharyngioma, and calcifying odontogenic cyst. Am J Clin Pathol. 2003; 120(5): 732-6. PubMed Abstract | Publisher Full Text

33. Hofmann BM, Kreutzer J, Saeger W, et al:: Nuclear beta-catenin accumulation as reliable marker for the differentiation between cystic craniopharyngiomas and rathke cleft cysts: a clinico-pathologic approach. Am J Surg Pathol. 2006; 30(12): 1595-603.

PubMed Abstract | Publisher Full Text

34. Oikonomou E, Barreto DC, Soares B, et al:: Beta-catenin mutations in craniopharyngiomas and pituitary adenomas. J Neurooncol. 2005; 73(3): 205-9. PubMed Abstract | Publisher Full Text

35. Preda V, Larkin SJ, Karavitaki N, et al:: The Wnt signalling cascade and the adherens junction complex in craniopharyngioma tumorigenesis. Endocr Pathol. 2015; 26(1): 1-8 PubMed Abstract | Publisher Full Text

36. F Gaston-Massuet C, Andoniadou CL, Signore M, et al:: Increased Wingless (Wnt) signaling in pituitary progenitor/stem cells gives rise to pituitary tumors in mice and humans. Proc Natl Acad Sci U S A. 2011; 108(28): 11482-7. PubMed Abstract | Publisher Full Text | Free Full Text | F1000 Recommendation

37. F Andoniadou CL, Matsushima D, Mousavy Gharavy SN, et al:: Sox2(+) stem/ progenitor cells in the adult mouse pituitary support organ homeostasis and have tumor-inducing potential. Cell Stem Cell. 2013; 13(4): 433-45. PubMed Abstract | Publisher Full Text | F1000 Recommendation

38. Martinez-Barbera JP: Molecular and cellular pathogenesis of adamantinomatous craniopharyngioma. Neuropathol Appl Neurobiol. 2015; 41(6): 721-32.

PubMed Abstract | Publisher Full Text | Free Full Text

39. F Martinez-Barbera JP: 6O YEARS OF NEUROENDOCRINOLOGY: Biology of human craniopharyngioma: lessons from mouse models. J Endocrinol. 2015; 226(2): T161-72. PubMed Abstract | Publisher Full Text | F1000 Recommendation

40. Martinez-Barbera JP, Andoniadou CL: Concise Review: Paracrine Role of Stem Cells in Pituitary Tumors: A Focus on Adamantinomatous Craniopharyngioma. Stem Cells. 2016; 34(2): 268-76.

PubMed Abstract | Publisher Full Text | Free Full Text

41. Hölsken A, Stache C, Schlaffer SM, et al:: Adamantinomatous craniopharyngiomas express tumor stem cell markers in cells with activated Wnt signaling: further evidence for the existence of a tumor stem cell niche? Pituitary. 2014; 17(6): 546-56. PubMed Abstract | Publisher Full Text

42. F McGranahan N, Swanton C: Clonal Heterogeneity and Tumor Evolution: Past, Present, and the Future. Cell. 2017; 168(4): 613-28. PubMed Abstract | Publisher Full Text | F1000 Recommendation

43. Scagliotti V, Avagliano L, Gualtieri A, et al.: Histopathology and molecular characterisation of intrauterine-diagnosed congenital craniopharyngioma. Pituitary. 2016; 19(1): 50-6.

PubMed Abstract | Publisher Full Text 


\section{Open Peer Review}

\section{Current Peer Review Status:}

\section{Editorial Note on the Review Process}

Faculty Reviews are review articles written by the prestigious Members of Faculty Opinions. The articles are commissioned and peer reviewed before publication to ensure that the final, published version is comprehensive and accessible. The reviewers who approved the final version are listed with their names and affiliations.

\section{The reviewers who approved this article are:}

\section{Version 1}

\section{Juan Pedro Martinez-Barbera}

Developmental Biology and Cancer, UCL Great Ormond Street Institute of Child Health, University College London, London, UK

Competing Interests: No competing interests were disclosed.

\section{Hermann Müller}

Department of Pediatrics, Klinikum Oldenburg AöR, Medical Campus University Oldenburg, Oldenburg, Germany

Competing Interests: No competing interests were disclosed.

The benefits of publishing with F1000Research:

- Your article is published within days, with no editorial bias

- You can publish traditional articles, null/negative results, case reports, data notes and more

- The peer review process is transparent and collaborative

- Your article is indexed in PubMed after passing peer review

- Dedicated customer support at every stage

For pre-submission enquiries, contact research@f1000.com 